\title{
Food Security in Pakistan: Can It Be Achieved?
}

\author{
ATHER MAQSOOD AHMED and REHANA SIDDIQUi
}

\section{INTRODUCTION}

Wide fluctuations in world prices of food-grains, especially rice and wheat, in the seventies and the early eighties forced many developing countries to strive for self-sufficiency in food-grain production. Pakistan is among the countries where near self-sufficiency was achieved in wheat in the early eighties. It also maintained its status as a leading rice-exporting country. However, a continuously high rate of population growth, a changing pattern of income distribution, and a greater level of urbanisation have greatly influenced the demand for food-grains. At the same time, additional factors like a sharp rise in the cost of irrigation, a dramatic decline in the world price of rice, a heavy debt burden, the lack of technology and human capital development, and mismanagement in the distribution system have contributed towards a slower growth of grain production as compared with the levels achieved in the sixties and the eighties.

This change in the demand and supply situation with respect to food has necessitated the need to re-evaluate the existing agricultural policies. Within demand and supply constraints, the question is whether or not Pakistan can attain selfsufficiency in wheat while at the same time maintaining its status as a significant exporter of rice. In the immediate future, the situation appears desperate, but in the long-run, when available resources are adequately utilised and consistent policies are adopted, there is hope and optimism. This study not only reviews the current food situation in Pakistan but also develops alternative policy scenarios which are consistent with the target of food security in Pakistan.

This paper is developed as follows. The second section reviews the current food situation in Pakistan briefly. Based on supply and demand elasticities, the baseline forecasts or the control solution is generated in the third section. Alternative policy scenarios are developed in the fourth section, and the last section concludes this study.

\section{THE FOOD SITUATION IN PAKISTAN}

Pakistan is among those countries where the food situation in recent years has not been very encouraging. Of late the demand for food, especially wheat, which is the main staple, has started to exceed its supply. Even when the supply situation was

Ather Maqsood Ahmed and Rehana Siddiqui both work as Senior Research Economist at the Pakistan Institute of Development Economics, Islamabad. 
better, there were problems with the distribution of food among different segments of the society which led to widespread under-nourishment of masses. ${ }^{1}$

On the demand side, the food security problem has been complicated by an unprecedented increase in population. Since the existing rate of population growth of over 3 percent per annum is expected to continue at least until year 2000, the total population of the country will increase from 119 million in mid-1992 to over 148 million by year 2000 . The total fertility rate will also remain well above the so-called "replacement level". At the same time, improvement in health-care facilities, which have already resulted in a remarkable decline in infant and child mortality rates during 1970 and 1992, has also contributed towards the high population rate in Pakistan. As a consequence, the per capita availability of food-grains, which was around 430 grams/day during 1976-80, is expected to get worse in the years to come.

As far as the supply of food-grains in Pakistan is concerned, it has remained erratic during the past four decades. This can be observed from wide variations in the growth rates of food production. The performance of the agriculture sector since 1959-60 amply shows that agriculture production received a tremendous boost in the sixties when new varieties of different crops were introduced and greater stress was laid on the use of modern inputs. This change, which is referred to as "Green Revolution" in the literature, resulted in the adoption of high-yielding or modern varieties of seeds, especially of wheat, rice, and cotton. As a result, the average annual growth in Pakistan's agriculture sector was around 5.07 percent during this period. However, this euphoria was short-lived as stagnation, climatic adversaries, and lack of motivation on the part of policy-makers as well as farmers resulted in a decline in growth in the agriculture sector, which was only 2.37 percent during 1970-80.

The dynamism was revived in the eighties when preferences, especially of rice-growing farmers, changed to high-yielding modern varieties such as Irri-6 and Basmati-385. With this change in attitude, there was an expansion in this sector which grew at an average annual growth rate of 5.44 percent during the eighties.

In recent years (since 1988), the production of wheat has been fluctuating between 14 and 16 million tonnes, whereas the production of rice has gone up to 4 million tonnes in 1993-94, from 3.2 million tonnes during 1989-92 [Government of Pakistan (1993-94)].

\section{FORECASTING THE FUTURE FOOD SITUATION: THE BASELINE SCENARIO}

The historical pattern of the demand and supply situation in the country

${ }^{1}$ Even though the daily per capita calorie supply in Pakistan has gone up from 1761 in 1965 to 2315 in 1986 [World Bank (1990)], the prevalence of malnutrition under the age of 5 during 1987-92 still continues to be around 40 percent [World Bank (1994)]. 
provides the necessary basis for predicting the future food situation in the country. However, to generate baseline forecasts, there is a need to estimate a supply-demand model for major food crops.

Based on the Extended Linear Expenditure System (ELES), income and price elasticities of demand have been estimated for different crops. These estimates are based on the household-level data from the Household Income and Expenditure Survey [Government of Pakistan (1987-88)]. The supply-side estimates for area, yield, and input demand functions have been generated on the basis of Mundlak's (1988) supply response approach where technology and quasi-fixed inputs are endogenously determined. ${ }^{2}$

The forecasts presented here not only depend on the estimated coefficients, they also rely on the assumed growth paths of the exogenous variables. The growth rates which generate these growth paths have been calculated on the basis of recent trends. The information provided in Table 1 reveals that the wholesale prices of wheat and maize are expected to grow by 5 percent during ex post and ex ante periods, which incidently happens to be the actual growth rate of these prices during the past five years. Similarly, the prices of Basmati and Irri varieties of rice are expected to increase by 7 percent and 6 percent, respectively. While the price of fertiliser is expected to increase by 3 percent per annum during the forecast period, the labour cost is expected to go up by 5 percent as a result of the increase in farm wages. Finally, population growth is expected to grow at the existing rate of 3.1; the per capita incomes in rural and urban areas are expected to rise by 1.62 and 1.63 percent, respectively.

Table 1

Assumed Growth Rates for Selected Exogenous Variables

\begin{tabular}{|c|c|c|c|}
\hline \multirow{4}{*}{$\begin{array}{l}\text { Wholesale Prices of } \\
\text { Wheat and Maize } \\
\text { Basmati Rice } \\
\text { Irri Rice }\end{array}$} & \multicolumn{3}{|c|}{ Value-added in Other } \\
\hline & 5.00 & Agriculture & 7.00 \\
\hline & 7.00 & & \\
\hline & 6.00 & $\begin{array}{l}\text { Value-added Index } \\
\text { in Non-agri. }\end{array}$ & 6.00 \\
\hline Fertiliser Price & 3.00 & Population & 3.01 \\
\hline $\begin{array}{l}\text { Labour Cost for } \\
\text { Wheat, Rice, } \\
\text { and Maize }\end{array}$ & 5.00 & $\begin{array}{l}\text { Per Capita Income } \\
\text { Rural } \\
\text { Urban }\end{array}$ & $\begin{array}{l}1.62 \\
1.63\end{array}$ \\
\hline
\end{tabular}

\footnotetext{
${ }^{2}$ The details of model specification and estimated elasticities are not reported in this paper due to page restrictions. However, detailed discussion can be found in Siddiqui and Ahmed (1994) and Ahmed and Siddiqui (1994).
} 
Based on these growth paths and the estimated coefficients of the supply and demand models, the baseline solutions (projections) until year 2009-10 are reported in Table 2. ${ }^{3}$ The results suggest that although per capita demand for wheat will decline slowly due to a negative response to the changes in income, yet the aggregate demand for wheat will increase; which implies that if population continues to grow at the same rate as it is now, the total demand for wheat will increase from 17.2 million tonnes in 1994-95 to 26.5 million tonnes by 2009-10. ${ }^{4}$ Similarly, the expected demand for rice and maize will roughly double during this period. But since rice is not a major food item of consumer budget in Pakistan, the income effect is expected to dominate the population growth effect.

The production of wheat, on the other hand, is not expected to rise at a fast enough rate to match the rising domestic demand during 1990-91 and 2009-10. Thus, while the production will increase from 14.8 million tonnes in 1990-91 to 20.0 million tonnes in 2009-10 - an average annual growth of only 1.6 percent-the consumption (demand) for wheat will rise by an average annual rate of 2.91 percent during this period. The need to import wheat from international sources will, therefore, increase from less than one million tonnes in 1994-95 to 6.4 million tonnes by 2009-10. Similarly, self-sufficiency in maize will also be at stake during the next 15 years. From a maize surplus economy, the country will barely fulfil its food and feed needs by 2010 .

So far as baseline projections for rice production are concerned, the results indicate that it will increase at an average annual rate of 0.68 percent during 199495 and 1999-2000. This growth will, however, accelerate to over 4 percent per annum beyond year 2000. The overall growth of rice production during the forecast period will be 2.81 percent. Since the demand for rice will be increasing at a faster rate (3.97 percent), it will exert extra pressure on Pakistan's rice exports. However, if the baseline scenario prevails, then Pakistan will continue to export around one million tonnes of rice during the next fifteen years. ${ }^{5}$

\section{ALTERNATIVE SCENARIOS}

\section{The Demand-side Policy Simulation}

The demand-side policy simulation concerns controlling population growth, improvement in the distribution of income, and the growth of per capita income in the urban and rural areas. For the policy experiment under consideration, it is

\footnotetext{
${ }^{3}$ The model solution has been generated by applying Newton's method, which involves interaction as well as linearalisation and matrix inversion. For details, see Saaty and Bram (1964).

${ }^{4}$ The table is taken out due to page limit on the paper. However, it is available from the authors.

${ }^{5}$ Even though we predict an acceleration in rice growth, yet it may be noted that this acceleration will be possible only if there is adequate investment in irrigation and extension to save water losses between canal-head and farm-gate and if appropriate measures are taken to preserve cultivated area from the menace of waterlogging and salinity.
} 
assumed that population growth rate will gradually decline from 3.1 percent in 199394 to 2.6 percent by 2004-5. It will further decline to 2.5 by 2010 . At the same time, the growth in income in the urban and rural areas of Pakistan will resemble that prevailing in the province of Punjab. In particular, this experiment assumes that income growth in the rural areas will be 1.90 percent per annum, and that for the urban areas it will be 2.81 percent per annum. This scenario further assumes that the inflation rate will remain stable, i.e., all prices will change at the constant rate, and that tastes will not change over time.

The results reported in Table 3 confirm that the slowing down of population growth will have a favourable impact on wheat demand and the growth in per capita income will influence rice demand. ${ }^{6}$ The demand for wheat will decline from 26.5 million tonnes under the baseline solution to 24.3 million tonnes under the present policy shock. As a consequence, the import requirement of wheat by 2009-10 will be nearly four million tonnes. This means that appropriate policy measures to control the population and raise the per capita income will reduce the wheat import requirement by more than two million tonnes by 2010, which by any standard is no small gain.

Similarly, this policy scenario will leave a beneficial demand effect on rice and maize. While rice exports are expected to increase by 70 thousand tonnes by 2010 as compared to the baseline solution, the surplus of maize will also increase from 29 thousand tonnes to 93 thousand tonnes during this period.

This outcome is promising, at least for two reasons. First, this scenario assumes a gradual decline in population, which is more realistic as compared to what has been assumed either in the baseline solution or in the Eighth Five-Year Plan document; and second, the income growth in urban and rural areas which this policy experiment postulates is already prevailing in the provinces of the Punjab and Balochistan. By channelling the information and by adopting consistent policies, there is every likelihood that the growth pattern of per capita income of the Punjab and Balochistan could be replicated in the provinces of Sindh and the NWFP as well.

\section{The Supply-side Policy Simulation}

The supply-side scenario assumes that the wholesale prices of wheat, rice, and maize will rise at relatively faster rates as compared to those assumed for the baseline solution. In particular, it has been assumed that:

(a) The price of wheat will increase by 10 percent as against 5 percent assumed in the control solution.

(b) The price of Basmati rice will increase by 9 percent as against 7 percent assumed in the control solution.

(c) The rate of growth of Irri rice will decline to 4 percent as against 6 percent assumed for the baseline solution.

${ }^{6}$ The table is available from the authors. 
(d) The price of maize will increase by 6 percent instead of 5 percent.

The results reported in Table 4 indicate that a rise in the wholesale prices of wheat, rice, and maize will be output-increasing: the production of rice will increase to 4951 thousand tonnes in 2009-10 as against 4889 thousand tonnes in the baseline solution. ${ }^{7}$ Consequently, given the demand pattern, the exportable surplus of rice will increase by 62 thousand tonnes. On the other hand, as a result of the present supply shock, wheat production in 2009-10 will increase by 2.6 percent as compared to the baseline solution. Even though the impact of price change in this case appears nominal, it will, nonetheless, reduce the import requirement of wheat by 521 thousand tonnes in 2009-10. Finally, price incentives for the farmers will result in an increase in maize production. However, as expected, the effect will not be as pronounced, as the suggested increase in price in 'real' terms is not very significant.

\section{CONCLUDING REMARKS}

As population growth shows no sure sign of declining significantly, and because world prices of food-grains continue to be unstable, the need for attaining food security has greater urgency. Also there is a need for attaining a dynamic intercrop equilibrium to emphasise the importance of rice and cotton as major foreign exchange earners. Historical data indicate that Pakistan, which was about to attain near self-sufficiency in wheat during the first half of the eighties, has almost lost this opportunity. As a result of the increasing domestic demand for wheat, the import requirement, on average, has increased to more than 2 million tonnes since 1988-89. This deficit in wheat production has, to some extent, been counter-balanced by the surplus production of rice. However, whether or not rice can substitute wheat depends largely on the eating habits of the masses, and also on the income elasticity of rice, especially Basmati rice. Another disturbing feature is the precarious position of rice as a major export item.

This study presented the baseline and alternative scenarios to evaluate the current situation as well as the future needs of these important food crops in the country. The baseline solution shows that if no suitable policy measures are taken, then the shortage of wheat is expected to increase manifold by 2010; and the same will be the case for maize. On the other hand, by changing food habits and an improvement in income distribution, the exportable surplus of rice will reduce during the next 15 years. This portrays a desperate food security situation which requires immediate attention.

To see whether any meaningful policy action can avert this dismal situation, we conducted demand and supply policy experiments. The two scenarios presented here do provide some hope for the future. It appears that if proper incentives are

${ }^{7}$ The table is available from the authors. 
provided to the farmers and the rapid growth in population is checked by a conscious policy action, then Pakistan can reduce its dependency on imported food, especially wheat. Similarly, it can continue to earn valuable foreign exchange through rice exports, whose volume will crucially depend on investment in irrigation and extension and the use of yield-improving technologies.

\section{REFERENCES}

Ahmed, A. M., and R. Siddiqui (1994) Supply Response in Pakistan with 'Endogenous' Technology. The Pakistan Development Review 33:4 871-888.

Mundlak, Y. (1988) Endogenous Technology and the Measurement of Productivity. In S. M. Cepalbo and J. M. Antle (eds) Agricultural Productivity: Measurement and Explanation. Washington, D. C.: Resources for Future.

Pakistan, Government of (1993-94) Pakistan Economic Survey (1993-94). Islamabad: Ministry of Finance, Economic Adviser's Wing.

Pakistan, Government of (1987-88) Household Income and Expenditure Survey (1987-88). Islamabad: Statistics Division, Federal Bureau of Statistics.

Saaty, T. L., and J. Bram (1964) Nonlinear Mathematics. New York: McGraw-Hill Book Company.

Siddiqui, R., and A. M. Ahmed (1994) Demand for Food Grains in Pakistan. Paper presented at the Third Workshop on Projections and Policy Implications of Medium- and Long-term Rice Supply and Demand. IRRI/IFPRI.

World Bank (1990) The World Development Report 1990. Oxford: Oxford University Press.

World Bank (1994) The World Development Report 1994. Oxford: Oxford University Press. 


\section{Comments}

Food security is not only the concern of Pakistan but also a sensitive global issue. The normal supply and demand operations have drastically altered. Once there are shortages, the famine psyche sets in which plunges the whole supply and demand equation into an almost insoluble problem.

The paper by Ahmed and Siddiqui provides a stimulating analysis of the baseline and alternative scenarios. They have used the demand-side policy simulation and the supply-side policy simulation to evaluate the current situation as well as the future need of food crops in Pakistan.

The baseline solution shows that if suitable measures are not taken, the shortage of wheat is expected to increase manifold by 2010; and the same goes for maize. The authors further state that due to changes in income distribution, the exportable surplus of rice will decrease during the next 15 years. They emphasise that this portrays a desperate food security situation which requires immediate attention. In order to avert serious problems, the authors have conducted the demand and supply policy analysis. The paper recommends proper incentives for farmers and population control so that Pakistan can reduce its dependency on imported food.

The paper is interesting and the authors have made a creditable effort. The comments below can improve it further.

Food security issue is not only the demand- and supply-side scenario, it also concerns the earning power or exchange value [Sen (1981)]. Alderman (1990) described two dimensions of food security, i.e., the household and the market level, and both have transitory as well as chronic dimensions.

It is worthwhile to aggregate the average value of net cereal import. Pakistan's performance is the highest among South Asian countries, although it decreased from -279 to -124 in the period 1980-85 to 1985-1990 [Chaudhry (1994)]. So analysing only on the production basis may provide a different picture. There is a comparative advantage in exporting rice and importing wheat due to international prices of wheat and rice.

The authors' picture of demand and supply of major food crops in all scenarios looks pessimistic if we compare it with that of the Task Force on Agriculture Report (1993). The three percent increase in fertiliser price on the supply side and constant inflation on the demand side are assumptions which are not realistic. The present double digit inflation and the tremendous increase in fertiliser prices affect the analysis. Furthermore, in the supply-side policy simulation, the authors assume that wholesale prices will rise at a faster rate for wheat, rice, and

maize. This might be true for wheat and maize but it contradicts their introductory 
statement about the dramatic decline in world price of rice which would retain the same momentum in future.

The control of population is of course necessary but the incentive the authors propose for the farmers needs elaboration. There is also a need to improve the basic infrastructure, agricultural research, education and extension services, etc.

Agricultural Economics Research Unit,

Usman Mustafa

Arid Zone Research Institute,

Pakistan Agricultural Research Council,

Quetta.

\section{REFERENCES}

Alderman, Harold (1991) Issues for Food Security in Rural Pakistan. Proceedings of the First International Conference on Agricultural Strategies in the 1990s: Issues and Policies. Pakistan Association of Agricultural Social Sciences, PARC, Islamabad. May 7-9.

Chaudhry, M. Ghaffar (1994) Transformation of Agriculture, Food Self-sufficiency, and Prospects for Surplus: The Case of South Asia. Journal of Contemporary South Asia 3:1 37-52.

Sen, Amartya (1981) Poverty and Famines: An Essay on Entitlement and Deprivation. Oxford: The Clarendon Press.

Task Force on Agriculture (1993) Report of the Prime Minister's Task Force on Agriculture. Revenue Division, Ministry of Finance, Revenue and Economic Affairs, Government of Pakistan, Islamabad. 